\title{
Rekayasa Aplikasi Ensiklopedia Tanaman Obat Berbasis Android
}

\author{
Dewi Eka Sari ${ }^{1)}$, Shinta Puspasari ${ }^{2}$, Hastha Sunardi ${ }^{3)}$ \\ ${ }^{122) 3)}$ Program Studi Informatika Universitas Indo Global Mandiri \\ Jl. Jend. Sudirman No. 629 KM.4 Palembang Kode Pos 30129 \\ Email:dewi_eka_sari@yahoo.com ${ }^{l)}$, shinta.puspasari@gmail.com $^{2}$, hastha_s@uigm.ac.id $^{3)}$
}

\begin{abstract}
The insufficiency of information to the society regarding about medicinal plants causes the lack of knowledge of the community will the efficacy of medicinal plants that have many health benefit. Nevertheless, the data of medicinal plants have not been properly managed and have not been documented and stored digitally, then built Engineering Application Of Medicinal Plants Based Android to facilitate the public in getting information about medicinal plants. This application is expected the public to obtain information and knowledge about the efficacy of medicinal plants effectively, efficiently and improve public health by utilizing medicinal plants that exist around our environment. The method used of this application is Rational Unified Process (RUP) and modeling Unified Modeling Language (UML). Based on questionnaires to users of application, obtained the results of $87 \%$ of respondents stated that applications running on Android easy to use by users and 86\% also respondents stated that the application on Android has a good design
\end{abstract}

Keywords: Encyclopedia, Medicinal Plants, Android, RUP

\section{Abstrak}

Ketidakcukupan informasi kepada masyarakat tentang tanaman obat menyebabkan kurangnya pengetahuan masyarakat akan keampuhan tanaman obat yang memiliki banyak manfaat kesehatan. Namun demikian, data tanaman obat belum dikelola dengan baik dan belum didokumentasikan dan disimpan secara digital, kemudian dibangun Aplikasi Teknik Tanaman Obat Berbasis Android untuk memudahkan masyarakat dalam mendapatkan informasi tentang tanaman obat. Aplikasi ini diharapkan masyarakat untuk memperoleh informasi dan pengetahuan tentang khasiat tanaman obat secara efektif, efisien dan meningkatkan kesehatan masyarakat dengan memanfaatkan tanaman obat yang ada di sekitar lingkungan kita. Metode yang digunakan dari aplikasi ini adalah Rational Unified Process (RUP) dan pemodelan Unified Modeling Language (UML). Berdasarkan kuesioner kepada pengguna aplikasi, diperoleh hasil 87\% responden menyatakan bahwa aplikasi yang berjalan di Android mudah digunakan oleh pengguna dan $86 \%$ juga responden menyatakan bahwa aplikasi di Android memiliki desain yang baik.

Kata kunci: Ensiklopedia, Tanaman Obat, Android, RUP 


\section{Pendahuluan}

Indonesia merupakan negara yang kaya akan beraneka ragam tumbuhan. Hal ini tentunya didukung oleh iklim tropis yang dimiliki Indonesia sehingga memungkinkan beraneka ragam tumbuhan hidup dan berkembang. Sebagian dari tumbuh-tumbuhan tersebut merupakan tumbuhan yang dapat dimanfaatkan untuk mengobati berbagai penyakit, tumbuhan tersebut biasa disebut sebagai tanaman obat. Tanaman obat banyak digunakan oleh masyarakat karena dikenal memiliki efek samping yang rendah dibandingkan obat-obatan kimia, sehingga dewasa ini banyak orang yang menggunakan tanaman obat untuk mengobati penyakit, serta mengurangi penggunaan obat-obatan kimia. Namun yang sering terjadi, tanaman-tanaman yang dapat berperan sebagai obat ini luput dari perhatian dikarenakan minimnya pengetahuan akan kehebatan penyembuh alami ini (Tuty Handayani, 2013). Beberapa contoh jenis tanaman yang dapat dimanfaatkan sebagai tanaman obat yaitu Bayam Merah, Daun Katuk, Brotowali Kumis Kucing, Keji Beling, Lidah Buaya, Mahkota Dewa dan Kunyit (Tuty Handayani, 2013).

Tanaman Obat sejauh ini masih mendapat tempat di hati masyarakat Indonesia. Selain harganya lebih ekonomis, tanaman obat minim efek samping dan aman digunakan untuk jangka panjang (Lioni Ellis, 2017).

Ensiklopedia adalah salah satu sarana untuk mendapatkan informasi tentang keaneragaman tanaman obat di Indonesia. Ensiklopedia ialah karya universal yang menghimpun uraian tentang berbagai cabang ilmu atau bidang ilmu tertentu dalam artikel-artikel terpisah dan tersusun menurut abjad. Ensiklopedia tanaman obat tradisional adalah suatu buku yang dapat memberikan informasi kepada pengguna mengenai jenis tanaman apa saja yang dapat digunakan untuk menyembuhkan berbagai macam penyakit.

Teknologi smartphone dan sejenisnya lebih banyak digunakan saat ini karena bisa dibawa kemana-mana dan mudah dalam pencarian informasi dibandingkan dengan menggunakan berbasis web, aplikasi yang berbasis android ini sangat mudah mengakses informasi tanaman obat nusantara tanpa harus memikirkan koneksi jaringan internet dan pulsa internet serta dapat gunakan seluruh penjuru daerah. Hal ini tentunya menjadi keunggulan tersendiri karena pengguna tidak usah repot membawa buku ensiklopedia yang berat ke mana-mana. Pengguna tinggal menggunakan aplikasi untuk mengetahui informasi tanaman obat tradisional tersebut dimana saja dan kapan saja.

\section{A. Perumusan Masalah}

Berdasarkan latar belakang yang telah dijabarkan diatas maka masalah yang akan dibahas adalah bagaimana membangun dan merancang aplikasi informasi tentang pengenalan tanaman obat nusantara yang dapat diakses oleh siapa saja, kapan saja dan dimana saja.

\section{B. Batasan Masalah}

Adapun beberapa batasan masalah dalam penelitian ini, yaitu:

1. Data tanaman yang digunakan sebanyak 70 jenis tanaman obat yang ada di bumi nusantara.

2. Aplikasi yang dibuat fokus dalam memberikan informasi tentang jenis-jenis tanaman obat nusantara berdasarkan kategori tanaman buah, tanaman sayuran dan tanaman rempah.

\section{Tujuan dan Manfaat Penelitian}

Adapun tujuan penelitian adalah merancang dan membangun aplikasi ensiklopedia tanaman obat berbasis android yang efektif dalam memberikan informasi tentang jenis-jenis tanaman yang dapat digunakan sebagai obat.

\section{Tanaman Obat}

Tanaman obat adalah tanaman yang memiliki khasiat obat dan digunakan sebagai obat dalam penyembuhan maupun pencegahan penyakit. Tercatat 940 tanaman obat telah didokumentasikan oleh Kementerian Kesehatan Republik Indonesia (Lioni Ellis, 2017). Pengertian berkhasiat obat adalah mengandung zat aktif yang berfungsi mengobati penyakit tertentu atau jika tidak mengandung zat aktif tertentu tapi mengandung efek resultan/sinergi dari berbagai zat yang berfungsi mengobati (Kuncoro DM, 2008). Tanaman obat tidak berarti tumbuhan yang ditanam sebagai tanaman obat.Tanaman obat yang tergolong rempah-rempah atau bumbu dapur, tanaman pagar, tanaman buah, tanaman sayur atau bahkan tanaman liar juga dapat digunakan sebagai tanaman yang di manfaatkan untuk mengobati berbagai macam penyakit.

Sejauh ini obat alami atau obat herbal masih mendapat tempat di hati masyarakat Indonesia Selain harga yang lebih ekonomis, obat herbal minim efek samping dan aman digunakan untuk jangka panjang (Lioni Ellis, 2017). Ada 70 jenis tanaman obat yang yang dirangkum dalam penelitian ini yang digunakan untuk mengobati berbagai macam penyakit secara tradisional/herbal, anatara lain alpukat, anggur, belimbing, delima, jambu biji, jeruk, pisang, manggis, sirsak, pepaya, nanas, kacang panjang, daun katuk, labu siam, melinjo, mentimun, tomat, wortel, kenikir, lobak, asam jawa, baang merah, bawang putih, brotowali, daun, kemangi, jahe, kayu manis, lengkuas, mengkudu, sirih, akar siyuh, alang-alang, ancang, cengkih, durian, anceng, jamur kuping, jamur tiram, jarak, keladi tikus, kemiri, kunyit, lempuyang, mahkota dewa, malaka, merica, murbei, pegagan, pisang kepok, pare, bayam, semangka, buncis, sereh, temulawak, daun salam, jengkol, daun salam, buah naga, singkong, daun saga, putri malu, rosella, sarang semut, sidaguri dan turi

\section{E. Ensiklopedia}

Ensiklopedia atau Encyclopaedia yang asal katanya dari bahasa Yunani (Greek), yaitu egkuklios, adalah cyclon, all round (siklus) dan paedia adalah education, knowledge atau pengetahuan, widya. Dengan demikian 
pengertian dari Encyclopaedia ialah siklus ilmu pengetahuan atau ringkasan uraian ilmu pengetahuan. Menurut Kamus Besar Bahasa Indonesia (KBBI) edisi ketiga tahun 2008, Ensiklopedia ialah karya universal yang menghimpun uraian tentang berbagai cabang ilmu atau bidang ilmu tertentu dalam artikel-artikel terpisah dan tersusun menurut abjad.

Ensiklopedia merupakan kelompok buku referensi selain dari kamus (dictionary). Secara umum Buku Referensi sering lebih dikenal dengan sebutan "Buku Rujukan”. Ada juga yang menyebutkan dengan Buku Panduan, Buku Acuan, Alat Bantu Cepat (Quick Help). Perbedaan Ensiklopedia dengan Kamus adalah Kamus berisikan arti kata dan berkaitan dengan kebahasaan, sedangkan Ensiklopedia berisikan lebih luas, dimana Ensiklopedia memuat artikel / topik, mengurai, mendefenisikan dan merangkai arti suatu artikel dari awal hingga akhir, baik penemuan suatu ilmu pengetahuan maupun peristiwa-peristiwa penting.

\section{F. Android}

Android adalah sebuah sistem operasi untuk perangkat mobile berbasis linux yang mencakup sistem operasi, middleware, dan aplikasi. Android menyediakan platform terbuka bagi para pengembang untuk menciptakan aplikasi mereka. Android adalah sistem operasi yang menghidupkan lebih dari satu miliar smartphone dan tablet. Karena perangkat ini membuat hidup kita begitu manis, maka setiap versi Android dinamai dari makanan penutup (dessert) (Putra et al., 2016). Android memiliki 4 (empat) karakteristik sebagai berikut :

1. Terbuka, Android dibangun untuk benar-benar terbuka sehingga sebuah aplikasi dapat memanggil salah satu fungsi initi ponsel seperti panggilan, mengirim pesan teks, menggunakan kamera, dan lain-lain.

2. Semua Aplikasi dibuat sama, Android tidak memberikan perbedaan terhadap aplikasi utama dari telepon dan aplikasi pihak ketiga (third-party application).

3. Memecahkan hambatan pada aplikasi. Android memecah hambatan untuk membangun aplikasi yang baru dan inovatif.

4. Pengembangan aplikasi yang cepat dan mudah. Android menyediakan akses yang sangat luas kepada pengguna untuk menggunakan library yang dipergunakan tools yang dapat digunakan untuk membangun aplikasi yang semakin baik.

\section{G. Unified Modeling Language (UML)}

Menurut Rosa A. S (Rekayasa Perangkat Lunak Terstruktur dan Berorientasi Objek 2013:137) Unified Modeling Language (UML) adalah bahasa visual untuk pemodelan dan komunikasi mengenai sebuah sistem dengan menggunakan diagram.

Unified Modeling Language (UML) merupakan sistem arsitektur yang bekerja dalam OOAD (ObjectOriented Analysis/Design) dengan satu bahasa yang konsisten untuk menentukan, visualisasi, mengkontruksi, dan mendokumentasikan artifact (sepotong informasi yang digunakan atau dihasilkan dalam suatu proses rekayasa software, dapat berupa model, deskripsi, atau software) yang terdapat dalam sistem software. UML merupakan bahasa pemodelan yang paling sukses dari tiga metode OO yang telah ada sebelumnya, yaitu Booch, OMT (Object Modeling Technique), dan OOSE (Object-Oriented Software Engineering).

\section{Pembahasan}

Metode pengembangan sistem yang digunakan dalam membangun Aplikasi Ensiklopedia Tanaman Obat Berbasis Android adalah Metode Rational Unified Process (RUP).

Tahap identifikasi adalah tahap dimana peneliti melakukan identifikasi interface untuk aplikasi yang didukung dengan observasi atau wawancara langsung kepada user. Penelitian dilakukan di Keluarahan Air Batu Rt.01 Banyuasin. Objek penelitian ini adalah alasan kenapa masyarakat kurang mendapatkan informasi tentang jenis-jenis tanaman yang dapat digunakan sebagai obat.

Gambar use case pada aplikasi berbasis Android Android pada penelitian ini dapat dilihat pada Gambar 1.

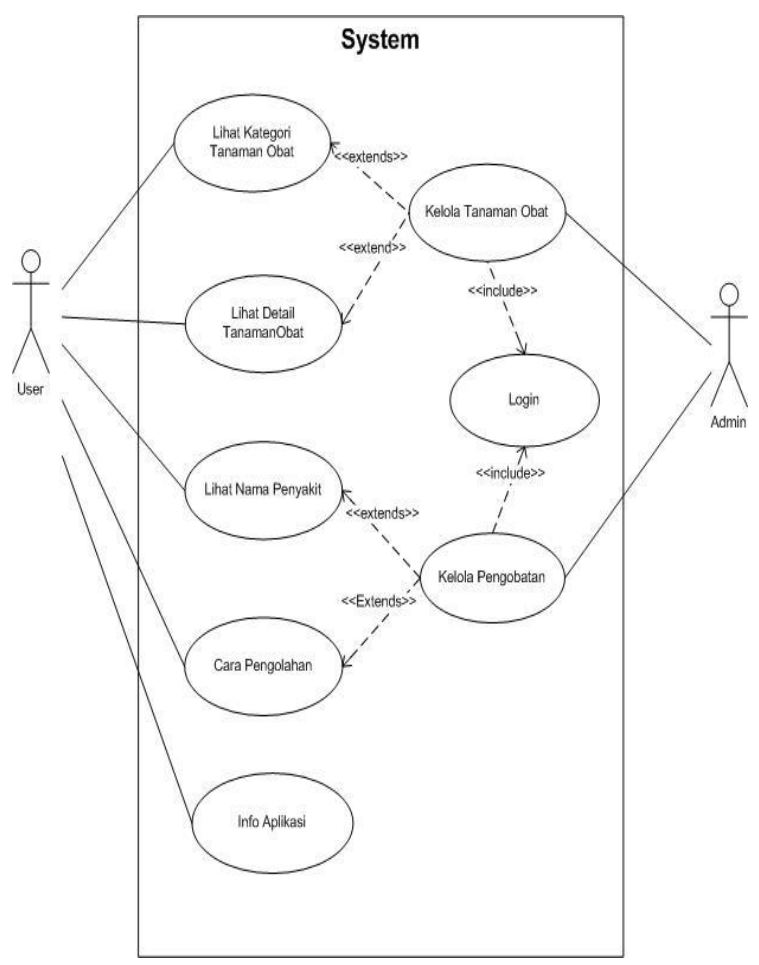

Gambar 1. Use Case Aplikasi Ensiklopedia Tanaman Obat Berbasis Android

Berikut ini adalah hasil dari implementasi aplikasi Rekayasa Aplikasi Ensiklopedia Tanaman Obat Berbasis Android pada emulator Android di Android Studio pada Personal Computer (PC). 


\section{A. Antarmuka Halaman Awal}

Antarmuka halaman awal merupakan halaman yang akan tampil pertama kali ketika Rekayasa Aplikasi Ensiklopedia Tanaman Obat Berbasis Android dijalankan. Pada antarmuka ini menampilkan splash screen sebagai halaman pembuka / halaman awal pada aplikasi ini seperti pada Gambar 2.

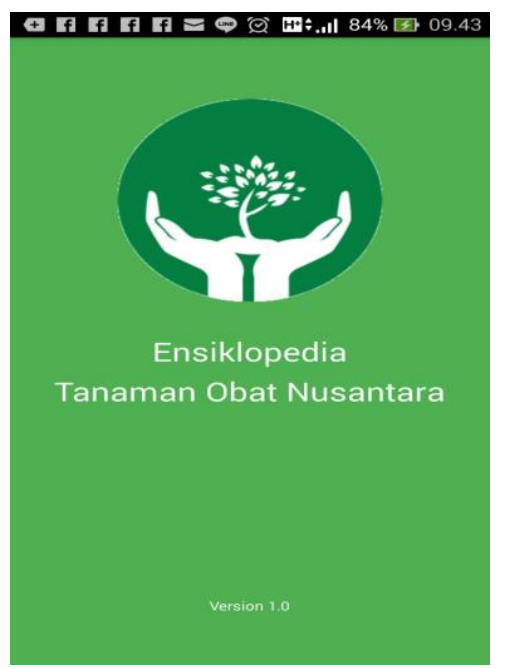

Gambar 2. Antarmuka Halaman Awal

\section{B. Antarmuka Menu Utama}

Pada halaman menu utama terdapat tiga pilihan menu yaitu Tanaman Obat yang berisikan informasi dari jenis tanaman obat. Resep Obat berisi informasi cara pengolahan tanaman obat sesuai penyakit yang diderita. Info Aplikasi berisi informasi tentang aplikasi dan pengembang aplikasi.

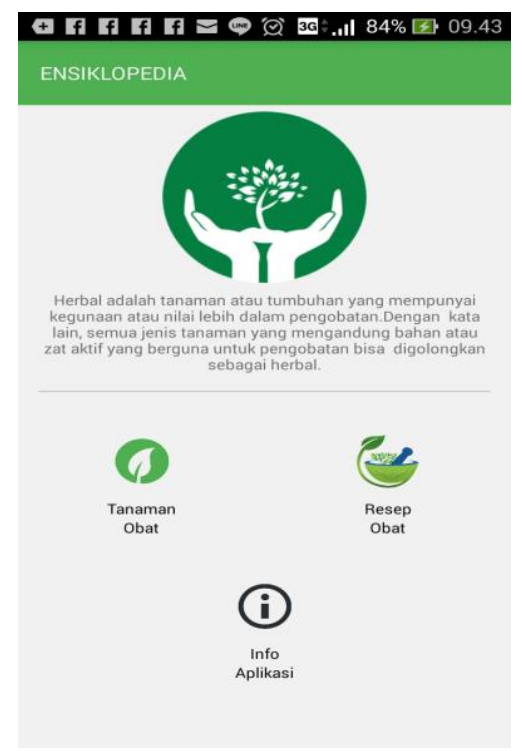

Gambar 3. Antarmuka Menu Utama

\section{Antarmuka Pilih Menu Tanaman Obat}

Pada menu utama user memilih menu tanaman obat dan kemudian tampil halaman kategori tanaman obat seperti pada Gambar 4. Pada tampilan ini user harus memilih kategori tanaman obat yang sudah disediakan.
Terdapat 3 (dua) pilihan kategori, yaitu kategori Buah, Kategori Sayuran dan Kategori Rempah-rempah. Cara pemilihan kategori dengan melakukan klik button pada kategori tanaman obat yang diinginkan untuk mendapatkan informasi jenis-jenis tanaman obat.

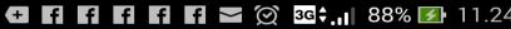

$\leftarrow \quad$ Jenis Tanaman

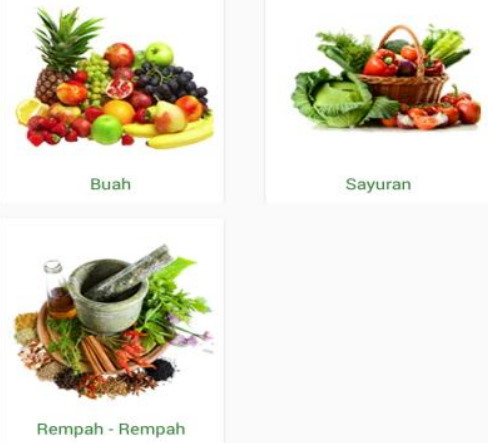

Gambar 4 Antarmuka Menu Tanaman Obat

\section{Antarmuka Detail Tanaman Obat}

Setelah user klik button untuk memilih salah satu kategori tanaman obat, pada antarmuka akan tampil jenis-jenis tanaman obat seperti pada Gambar 5(a)(b)(c). Untuk mendapatkan detail informasi tentang tanaman obat user harus klik button pada salah satu jenis tanaman obat yang ada pada tampilan seperti pada Gambar $5(a)(b)(c)$.

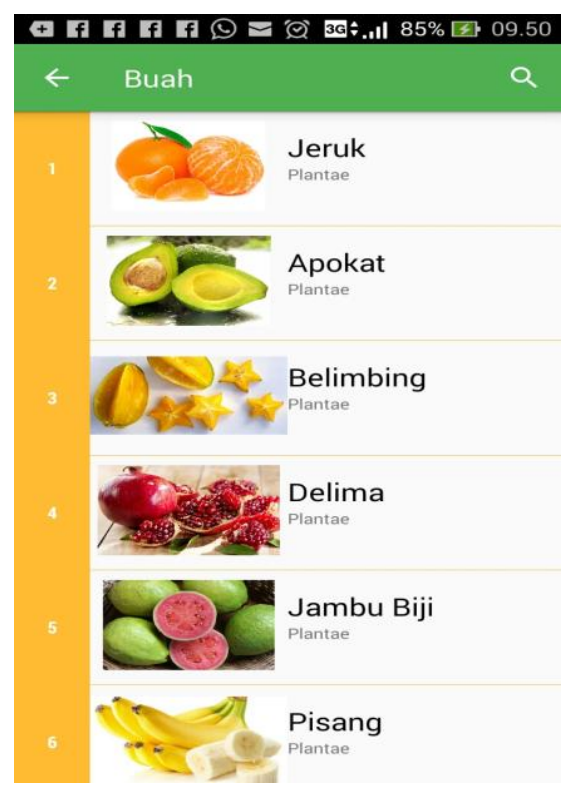

Gambar 5(a) Antarmuka Detail Tanaman Obat (Kategori Buah) 


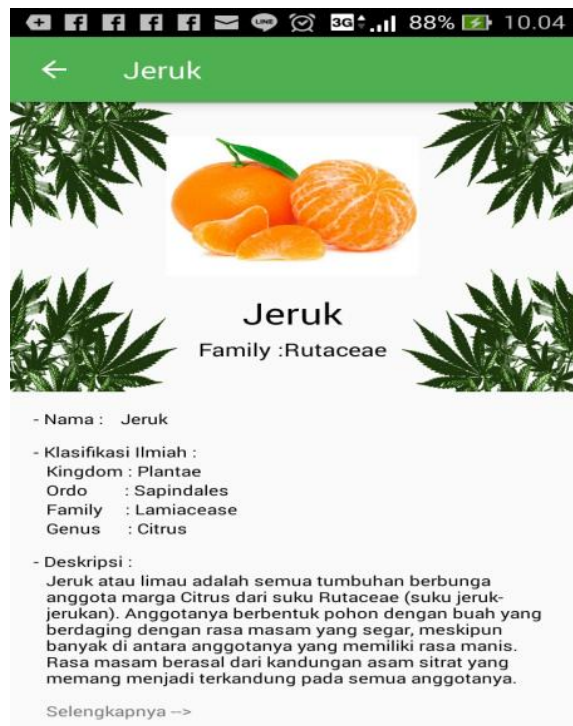

Gambar 5(b) Antarmuka Detail Tanaman Obat (Kategori Sayuran)

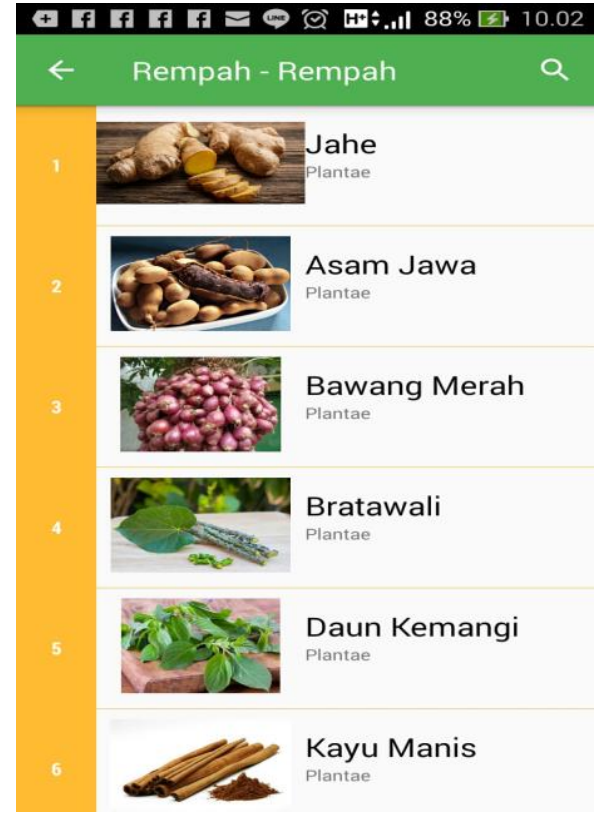

Gambar 5(c) Antarmuka Detail Tanaman Obat (Kategori Rempah-Rempah)

E. Antarmuka Jenis Tanaman Obat

Pada tampilan ini user memilih salah satu jenis tanaman obat, kemudian akan tampil nama-nama tanaman obat yang diinginkan. Dimana pada tampilan ini terdapat memuat informasi tentang tanaman obat mulai dari klasifikasi tanaman dan deskripsi tentang tanaman obat seperti pada Gambar 6(a)(b)(c). Untuk memperoleh informasi secara detail tentang tanaman obat tersebut user bisa browser ke website dengan klik link "selengkapnya $\rightarrow$ " yang ada pada tampilan antarmuka ini.

Dibawah ini merupakan antarmuka jenis tanaman obat katagori buah dapat ditunjukkan pada gambar dibaah ini

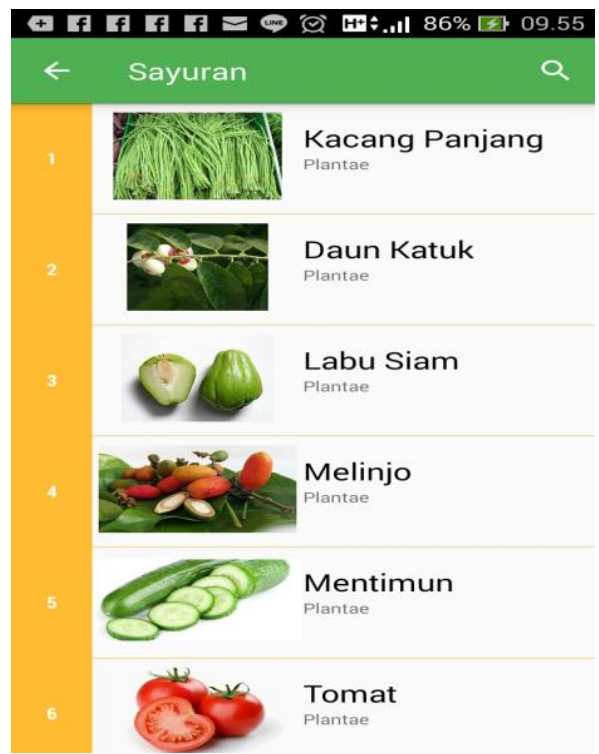

Gambar 6(a) Antarmuka Jenis Tanaman Obat (Kategori Buah)

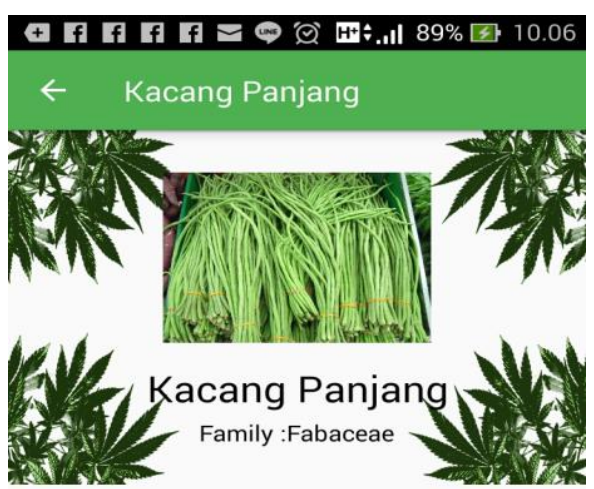

Nama : Kacang Panjang

Klasifikasi Ilmiah :

Kingdom : Plantae

Ordo : Fabales

Family : Lamiacease

Genus : Vigna

Deskripsi :

Kacang panjang merupakan tumbuhan yang dijadikan sayur atau lalapan. la tumbuh dengan cara memanjat ata mellit. Bagian yang dijadikan sayur atau lalapan adalah kacang panjang ini mudah didapati dikawasan panas d Asia Daunnya disebut dengan lembayung dan dapat dijadikan sayuran hijau.

Selengkapnya $\rightarrow$

Gambar 6(b) Antarmuka Jenis Tanaman Obat (Kategori Sayuran) 


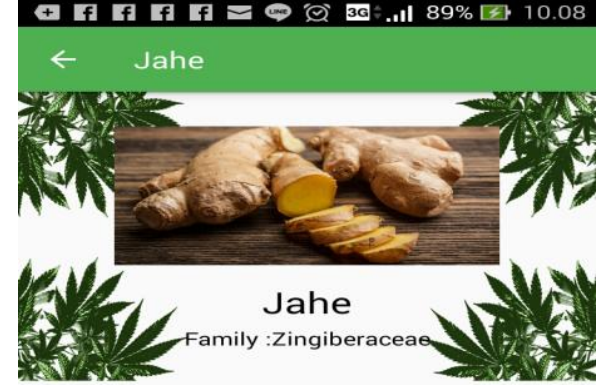

-Nama : Jahe

Klasifikasi Ilmiah :

Kingdom : Plantae

Ordo : Zingiberales

Genus Zingiber Mill

Deskripsi

Jahe (Zingiber officinale), adalah tanaman rimpang yang

(n) obat.

ruas tengah. Rasa dominan pedas disebabkan senyawa

ku Zingiberaceae (temu-temuan). Nama

ilmiah jahe diberikan oleh William Roxburgh dari kata

Yunani zingiberi, dari Bahasa Sanskerta, singaberi.

Rimpang jahe, terutama yang dipanen pada umur yan
masih muda tidak bertahan lama disimpan di gudang

Gambar 6(c) Antarmuka Jenis Tanaman Obat (Kategori Rempah-Rempah)

\section{F. Antarmuka Info Aplikasi}

Saat user memilih Info Aplikasi pada Menu Utama maka aplikasi akan menampilkan halaman informasi tentang pengembang aplikasi yang dibangun.

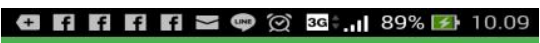

$\leftarrow \quad$ Tentang Aplikasi

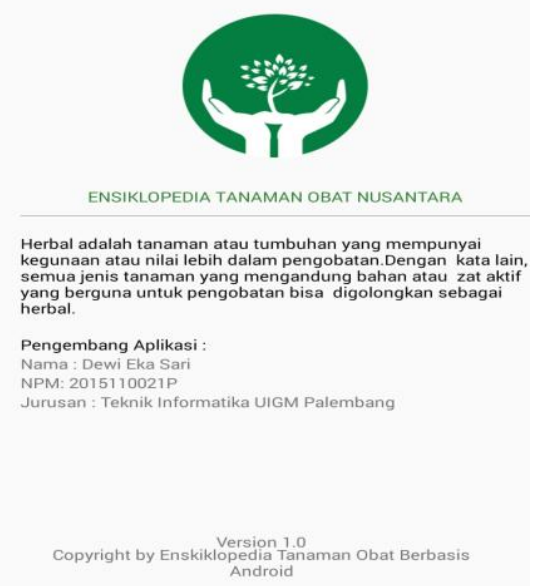

Gambar 7 Antarmuka Info Aplikasi

\section{G. Antarmuka Login}

Pada saat admin ingin menambahkan, mengubah atau menghapus data tentang tanaman obat, admin cukup masuk kedalam aplikasi berbasis web. Admin mengetikan http://localhost/phpmyadmin/ pada alamat website, kemudian aplikasi akan tampil seperti pada Gambar 8. Admin mengisi username dan password kemudian tekan login.

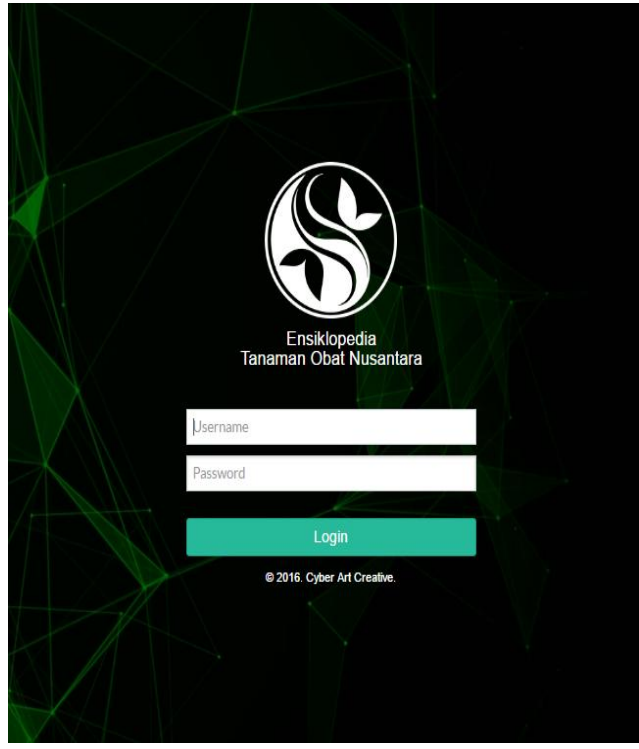

Gambar 8 Antarmuka Login

\section{H. Antarmuka Kelola Data}

Setelah Admin berhasil Login, maka akan tampil halaman untuk admin memperbarui data seperti pada Gambar 9 dan memilih tambah data untuk menambah data yang baru. Untuk mengubah dan menghapus data, pastikan user harus memilih terlebih dahulu data yang akan di ubah atau di hapus, setelah data dipilih kemudian klik ubah atau hapus.

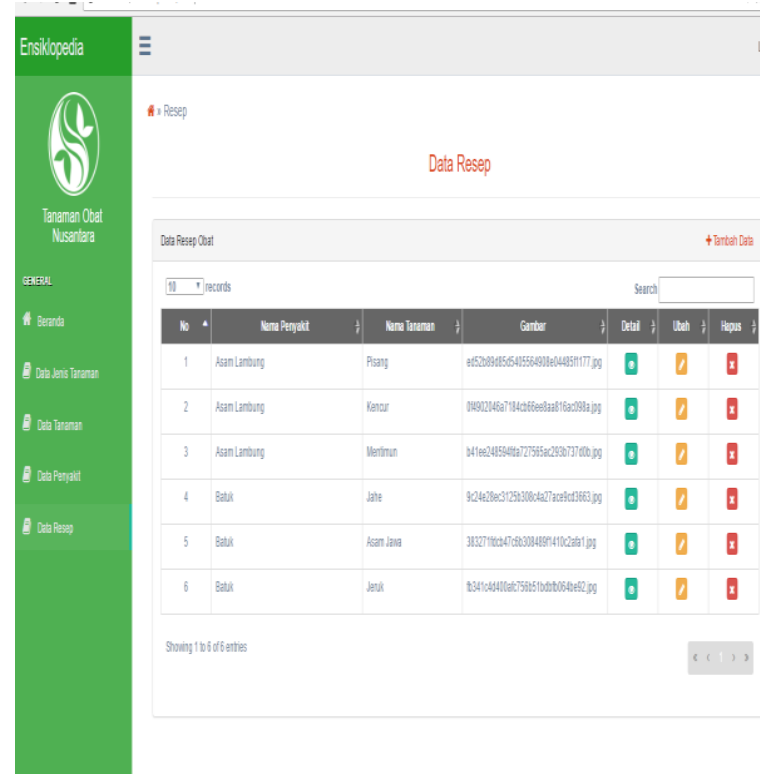

Gambar 9(a) Antarmuka Kelola Tanaman Obat 


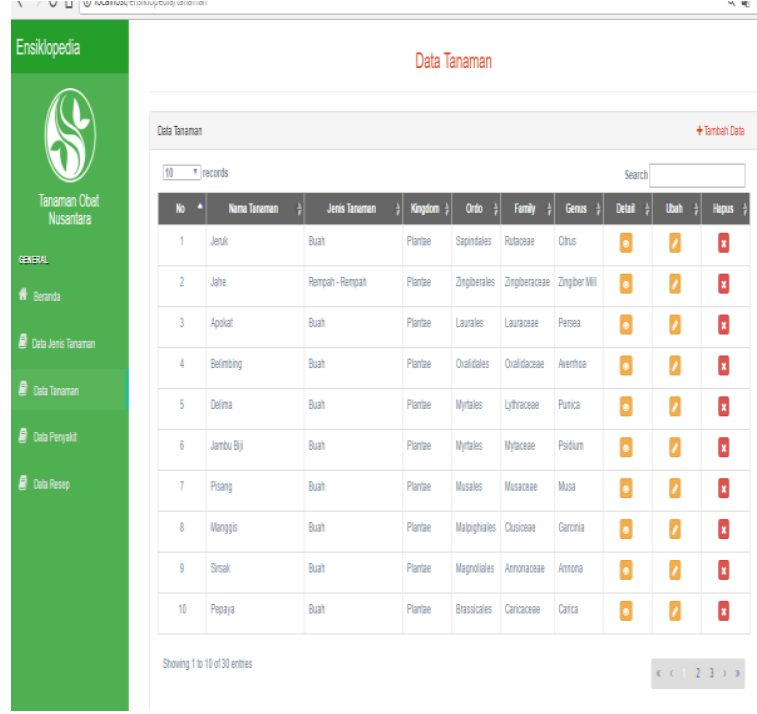

Gambar 9(b) Antarmuka Kelola Pengobatan

Pengujian Black Box dimaksudkan untuk mengetahui apakah fungsi-fungsi, masukan, dan keluaran dari perangkat lunak sesuai dengan spesifikasi yang dibutuhkan. Tujuan dari pengujian black box ini apakah komponen-komponen yang sudah ada berfungsi dengan baik, kesalahan pada antarmuka, kesalahan inisialisasi dan tujuan akhir.

Hasil pengujian Black Box dapat dilihat pada tabel-tabel dibawah ini.

\section{Pengujian Menu Awal}

Tabel 1 Pengujian Menu Halaman Awal

\begin{tabular}{|c|c|c|c|}
\hline Kelas Uji & $\begin{array}{c}\text { Skenario } \\
\text { Uji }\end{array}$ & $\begin{array}{c}\text { Hasil yang } \\
\text { diharapkan }\end{array}$ & Validasi \\
\hline $\begin{array}{l}\text { Menampilkan } \\
\text { Halaman Awal }\end{array}$ & $\begin{array}{l}\text { Memilih } \\
\text { Aplikasi } \\
\text { Ensiklopedia } \\
\text { Tanaman } \\
\text { Obat }\end{array}$ & $\begin{array}{l}\text { Menampilkan } \\
\text { Halaman Awal }\end{array}$ & Berhasil \\
\hline
\end{tabular}

\section{Pengujian Menu Utama}

Tabel 2 Pengujian Menu Utama

\begin{tabular}{|c|l|l|l|}
\hline \multirow{2}{*}{ Kelas Uji } & \multicolumn{1}{|c|}{$\begin{array}{c}\text { Skenario } \\
\text { Uji }\end{array}$} & \multicolumn{1}{|c|}{$\begin{array}{c}\text { Hasil yang } \\
\text { diharapkan }\end{array}$} & Validasi \\
\hline \multirow{5}{*}{ Menu Utama } & $\begin{array}{l}\text { Memilih } \\
\text { Kategori } \\
\text { Tanaman } \\
\text { Obat }\end{array}$ & $\begin{array}{l}\text { Menampilkan } \\
\text { Kategori Tanamar } \\
\text { Obat yang di Pilih }\end{array}$ & Berhasil \\
\cline { 2 - 4 } & $\begin{array}{l}\text { Memilih } \\
\text { Resep Obat }\end{array}$ & $\begin{array}{l}\text { Menampilkan } \\
\text { jenis-jenis } \\
\text { penyakit }\end{array}$ & Berhasil \\
\cline { 2 - 3 } & $\begin{array}{l}\text { Memilih Info } \\
\text { Aplikasi }\end{array}$ & $\begin{array}{l}\text { Menampilkan Inf } \\
\text { tentang aplikasi } \\
\text { yang dibangun }\end{array}$ & Berhasil \\
\hline
\end{tabular}

3. Pengujian Menu Tanaman Obat

Tabel 3 Pengujian Menu Pilih Tanaman Obat

\begin{tabular}{|l|l|l|l|}
\hline \multicolumn{1}{|c|}{$\begin{array}{c}\text { Kelas } \\
\text { Uji }\end{array}$} & $\begin{array}{c}\text { Skenario } \\
\text { Uji }\end{array}$ & \multicolumn{1}{|c|}{$\begin{array}{c}\text { Hasil yang } \\
\text { diharapkan }\end{array}$} & Validasi \\
\hline \multirow{4}{*}{$\begin{array}{l}\text { Menu } \\
\text { Pilih } \\
\text { Tanaman } \\
\text { Obat }\end{array}$} & $\begin{array}{l}\text { Memilih } \\
\text { Sayuran }\end{array}$ & $\begin{array}{l}\text { Menampilan jenis - } \\
\text { jenis tanaman obat } \\
\text { berdasarkan kategori } \\
\text { sayuran }\end{array}$ & Berhasil \\
\cline { 2 - 4 } & $\begin{array}{l}\text { Buah- } \\
\text { buahan }\end{array}$ & $\begin{array}{l}\text { Menampilan jenis - } \\
\text { jenis tanaman obat } \\
\text { berdasarkan kategori } \\
\text { buah-buahan }\end{array}$ & Berhasil \\
\cline { 2 - 5 } & $\begin{array}{l}\text { Memilih } \\
\text { Rempah- } \\
\text { rempah }\end{array}$ & $\begin{array}{l}\text { Menampilan jenis - } \\
\text { jenis tanaman obat } \\
\text { berdasarkan kategori } \\
\text { rempah-rempah }\end{array}$ & Berhasil \\
\hline
\end{tabular}

4. Pengujian Menu Pengobatan

Tabel 4. Pengujian Menu Pengobatan

\begin{tabular}{|l|l|l|l|}
\hline $\begin{array}{c}\text { Kelas } \\
\text { Uji }\end{array}$ & Skenario Uji & \multicolumn{1}{|c|}{$\begin{array}{c}\text { Hasil yang } \\
\text { diharapkan }\end{array}$} & Validasi \\
\hline & $\begin{array}{l}\text { Menampilkan } \\
\text { Jenis-jenis } \\
\text { penyakit }\end{array}$ & $\begin{array}{l}\text { Menampilkan } \\
\text { jenis penyakit } \\
\text { yang dipilih } \\
\text { sebelumnya }\end{array}$ & Berhasil \\
\cline { 2 - 4 } Menu & $\begin{array}{l}\text { Menampilkan } \\
\text { Resep } \\
\text { Obat }\end{array}$ & $\begin{array}{l}\text { Memilihan obat dan } \\
\text { cara pengolahan } \\
\text { jenis } \\
\text { penyaman yang } \\
\text { dijadikan sebagai } \\
\text { obat untuk } \\
\text { penyakit yang } \\
\text { dipilih } \\
\text { sebelumnya }\end{array}$ & Berhasil \\
\hline
\end{tabular}

5. Pengujian Menu Info Aplikasi

Tabel 5 Pengujian Menu Info Aplikasi

\begin{tabular}{|l|l|l|l|}
\hline \multicolumn{1}{|c|}{$\begin{array}{c}\text { Kelas } \\
\text { Uji }\end{array}$} & $\begin{array}{c}\text { Skenario } \\
\text { Uji }\end{array}$ & \multicolumn{1}{|c|}{$\begin{array}{c}\text { Hasil yang } \\
\text { diharapkan }\end{array}$} & Validasi \\
\hline $\begin{array}{l}\text { Menu } \\
\text { Info } \\
\text { Aplikasi }\end{array}$ & $\begin{array}{l}\text { Memilih } \\
\text { Info }\end{array}$ & $\begin{array}{l}\text { Menampilkan } \\
\text { informasi tentang } \\
\text { aplikasi yang } \\
\text { dibangun }\end{array}$ & Berhasil \\
\hline
\end{tabular}

Pengujian menggunakan kuesioner merupakan pengujian yang dilakukan secara objektif, dilakukan pengujian secara langsung terhadap pengguna. Responden dalam hal ini adalah ibu-ibu PKK Rt.01/02 kelurahan Air Batu yang berjumlah 20 orang. Jumlah pertanyaan yang ada di dalam kuesioner berjumlah 10 pertanyaan. 10 pertanyaan tersebut dibuat karena sudah cukup mewakili dari tujuan perancangan aplikasi ini. Pertanyaan yang diajukan dalam kuesioner untuk pengguna aplikasi ini adalah sebagai berikut : 
1. Apakah informasi yang disediakan oleh aplikasi ini mudah dimengerti ?

2. Apakah penggunaan menu atau fitur aplikasi menu mudah digunakan?

3. Secara keseluruhan apakah aplikasi ini memuaskan ?

4. Apakah aplikasi ini memberikan informasi sesuai keinginan pengguna?

5. Apakah aplikasi dapat dengan mudah dipelajari ?

6. Apakah aplikasi mudah dioperasikan ?

7. Apakah dapat dengan mudah menghindari kesalahan dalam menggunakan aplikasi ?

8. Apakah aplikasi bermanfaat bagi pengguna?

9. Apakah tampilan menu dalam aplikasi mudah untuk dikenali ?

10. Apakah aplikasi mempunyai kemampuan dan fungsi sesuai yang diharapkan?

Berdasarkan kuesioner terhadap pengguna aplikasi ini, diperoleh hasil sebesar $87 \%$ responden menyatakan bahwa aplikasi yang berjalan pada Android mudah digunakan oleh user dan $86 \%$ juga responden menyatakan bahwa pada aplikasi pada Android memiliki desain yang baik. Dapat disimpulkan bahwa aplikasi yang telah dibuat dinilai dapat dikategorikan baik sebagai media informasi, mempunyai tampilan menarik, mudah digunakan dan menambah wawasan mengenai tanaman-tanaman yang dapat dijadikan sebagai obat.

\section{Kesimpulan}

Berdasarkan hasil dan pembahasan Aplikasi Ensiklopedia Tanaman Obat Berbasis Android, maka dapat diambil kesimpulan sebagai berikut :

1. Dengan dibangunnya Aplikasi Ensiklopedia Tanaman Obat Berbasis Android ini diharapkan menjadi media alternatif sebagai bahan baca untuk mengenal dan mengetahui informasi tentang tanaman obat serta khasiatnya dalam menyembuhkan penyakit secara tradisional.

2. Hasil pengembangan Aplikasi Ensiklopedia Tanaman Obat Berbasis Android memberikan kemudahan kepada user dalam suatu pencarian informasi yang dibutuhkan tentang jenis-jenis tanaman yang dapat digunakan sebagai obat secara efektif dan efisien.

3. Berdasarkan kuesioner terhadap pengguna aplikasi ini, diperoleh hasil sebesar $87 \%$ responden menyatakan bahwa aplikasi yang berjalan pada Android mudah digunakan oleh user dan $86 \%$ juga responden menyatakan bahwa pada aplikasi pada Android memiliki desain yang baik.

\section{Saran}

Berikut ini saran yang dapat diberikan untuk pengembangan aplikasi :

1. Aplikasi yang dibangun hanya dapat digunakan pada Smartphone Android, diharapkan untuk kedepannya dapat berjalan dalam berbagai platform, seperti $i O S$, Windows Phone, Blackberry dan platform lainnya.
2. Menambahkan lebih banyak lagi informasi tentang tanaman obat yang belum termuat di dalam aplikasi ini.

\section{Daftar Pustaka}

Aranta, Aisha, Terapi Herbal Dalam Al-Qur'an dan AsSunnah Pijat Refleksi \& Obat Kuno. Pustaka Sandro. Jakarta.

Dalimartha, Setiawan. 2009. Ensiklopedi Tanaman Obat, Pustaka Bunda. Jakarta.

Deanesa Mharfhin, Yuli Fitrisia, Sugeng Purwantoro. 2009. Aplikasi Ensiklopedia Dinamis Tanaman Herbal Berbasis Android. Jurnal Sekolah Tinggi Informatika \& Komputer. Malang.

DM, Kuncoro. 2008. Mengenal Tumbuh-Tumbuhan Berkhasiat Obat. CV. Amalia, Jakarta,

Ellis, Lioni. 2017. Super Plants For Super Health (Hidup Sehat dengan Memanfaatkan Tumbuhan Berkhasiat Indonesia). Metgra. Solo.

Suparni, I dan Ari Wulandari. 2017. Herbal Kalimantan, Rapha Publishing. Jakarta.

Maulana Ardian Hanifuddin. 2016. Aplikasi Pengenalan Tanaman Obat Keluarga Berbasis Android. Skripsi Universitas Dian Nuswantoro, Semarang.

M.A., Tuty Handayani. 2013. Apotek Hidup. Pustaka Makmur, Bandar Lampung.

Prabowo Pudjo Widodo dan Heriawati. 2011. Menggunakan UML. Informatika, Bandung.

Priyanti. 2011. Pemograman Android untuk Pemula. Cerdas Pustaka. Jakarta.

S, Rosa A, Dan M, Shalahuddin. 2013. Rekayasa Perangkat Lunak. Informatika. Bandung.

Safaat, Nazruddin. 2012. Pemrograman Aplikasi Mobile Smartphone Dan Tablet PC Berbasis Android. Informatika. Bandung.

Siregar, Ivan Michael. 2011. Membongkar Source Code berbagai Aplikasi Android. Gava Medika. Yogyakarta.

Sri Wulantari,Tuti Tri Susanti. Dewi. 2012. Rancang Bangun Aplikasi Edugame Pengenalan Tanaman Obat Tradisional Berbasis Unity 3D. Teknik Informatika STMIK MDP. Palembang. 